\title{
Existential experience of children undergoing chemotherapy regarding the importance of playing
}

\author{
Experiência existencial de crianças em tratamento quimioterápico sobre a importância do \\ brincar
}

Gilvânia Smith da Nóbrega Morais ${ }^{1}$, Solange Fátima Geraldo da Costa ${ }^{2}$, Jael Rúbia de Sá França ${ }^{2}$, Marcella Costa Souto Duarte ${ }^{3}$, Maria Emília Limeira Lopes² ${ }^{2}$ Patrícia Serpa de Souza Batista ${ }^{2}$

\begin{abstract}
Objective: to understand the existential experience of children undergoing chemotherapy on the importance of playing. Methods: qualitative research performed in the outpatient clinic of a teaching hospital with five children undergoing chemotherapy. Data were collected through the interviews and analyzed in the light of the Humanistic Nursing Theory. Results: the discourses revealed the children's understanding of their illness and their treatment, evidencing the deprivations experienced by them and the situation of emotional imbalance. Playing, according to the children's reports, elicited positive feelings and represented a way for time to pass faster. Conclusion: the chemotherapy treatment was considered ambiguous, being an unpleasant experience, but necessary for cure. The games in the outpatient chemotherapy service were a viable tool to deal with the discontent before the situation lived, provoking positive feelings such as happiness and satisfaction.
\end{abstract}

Descriptors: Child; Neoplasms; Play and Playthings; Outpatient Clinics, Hospital.

Objetivo: compreender a experiência existencial de crianças em tratamento quimioterápico sobre a importância do brincar. Métodos: pesquisa qualitativa realizada no ambulatório de um hospital escola com cinco crianças em tratamento quimioterápico. A coleta de dados foi realizada por meio da técnica de entrevista, e a análise dos dados ocorreu à luz da Teoria Humanística de Enfermagem. Resultados: os discursos revelaram a compreensão das crianças sobre sua doença e seu tratamento, evidenciando as privações vivenciadas por elas e a situação de desequilíbrio emocional. Brincar, segundo os relatos das crianças, suscitou sentimentos positivos, constituindo uma maneira de o tempo passar mais rápido. Conclusão: o tratamento quimioterápico foi considerado ambíguo, sendo uma experiência desagradável, mas necessária para cura. As brincadeiras no serviço de quimioterapia ambulatorial foram uma ferramenta viável para o descontentamento diante da situação vivida, suscitando sentimentos positivos, como felicidade e satisfação.

Descritores: Criança; Neoplasias; Jogos e Brinquedos; Ambulatório Hospitalar.

\footnotetext{
${ }^{1}$ Universidade Federal de Campina Grande. Campina Grande, PB, Brazil.

${ }^{2}$ Universidade Federal da Paraíba. João Pessoa, PB, Brazil.

${ }^{3}$ Centro Universitário de João Pessoa. João Pessoa, PB, Brazil.
} 


\section{Introduction}

There are several treatment modalities for childhood cancer, but chemotherapy is the primary alternative. Despite the satisfactory responses to antineoplastic chemotherapy, adverse reactions such as nausea and vomiting, weight gain, pain, hypersensitive reaction, alopecia, fatigue and fever compromise the child's quality of life ${ }^{(1)}$.

Besides these harmful and unintentional responses to chemotherapeutic drugs, there is the fact that children who are affected by cancer and depend on outpatient chemotherapeutic treatment need to return frequently to the hospital. Because of this, the children have to leave their friends and school which leads to the breaking of meaningful bonds, change of eating habits and adaptation of games to the demands of disease and therapy. The children's life is affected by the number of treatment cycles that they need to undergo.

In order to allow the children to be authentic, the inclusion of playful activities emerges as part of the nursing care for the health of children with cancer under outpatient chemotherapy. Playing helps children not only to better understand what is happening to them, but also to learn how to solve problems by reproducing the situation they have experienced, so as to take control over reality ${ }^{(2)}$.

Playing in the outpatient environment make children to develop, perceive and experience body movements; optimize coordinated activities; establish interpersonal relationships with other children and with nursing professionals; broaden language skills; express feelings and longings; and release fears, anguish and restlessness, externalizing the feelings and conflicts related to the chemotherapeutic treatment $t^{(3)}$.

Playing, in the context of nursing and outpatient services, also helps to prepare the children for the procedures, promoting their cooperation and adherence to treatment, as the children learn better about the meaning of chemotherapy and obtain some control over the established therapy ${ }^{(4)}$.
Thus, in the case of children affected by cancer and in outpatient treatment, playing contributes to an authentic nursing care, contemplating not only the biological aspect but also valuing the human and subjective dimension of childhood, as it allows the professionals to know and understand the world of children and their needs. It is in this perspective that the present study is inserted. The following guiding question was adopted: What is the existential experience of children undergoing chemotherapy treatment concerning the importance of playing?

The objective of this study was to understand the existential experience of children undergoing chemotherapy on the importance of playing.

\section{Methods}

This is a qualitative study carried out between May and October 2015, in the outpatient clinic of a teaching hospital in Campina Grande, PB, Brazil, which is a reference in pediatric oncology and provides care for approximately 40 children undergoing chemotherapy.

The outpatient chemotherapy service specifically directed to the care of these children consisted of a team of nine professionals, three oncologists, one clinician, three nurses and two nursing technicians.

Five children undergoing chemotherapy were included in the present study; the number of participants was determined by the saturation criterion, in which the affinity of ideas obtained expresses the core of the phenomenon investigated ${ }^{(5)}$. We selected children who were undergoing outpatient chemotherapy for at least 1 month, who were aged between 5 and 12 years, had consistent verbal skills, participated in at least 5 days of play activities, and had good physical conditions analyzed according to the Eastern Cooperative Oncology Group (ECOG) performance scale. The ECOG performance scale evaluates the functional performance of the patient - in this case, the oncologic child undergoing chemotherapy - and the score ranges from zero to 5: zero indicates that the patient is fully 
active, able to continue all the performance as before the disease, without restrictions; 1 indicates that the patient is restricted to engage strenuous physical activity, but is able to perform works of a mild or sedentary nature; 2 indicates that the patient is fully capable of self-care but unable to perform any work activities; out of bed for more than $50.0 \%$ of the time; 3 indicates that the patient is able to perform limited self-care capacity and is restricted to the bed or to the chair for more than $50.0 \%$ of the waking time; 4 indicates that the patient is completely limited and is not able to perform any self-care measure; restricted to bed or chair; and 5 indicates that the patient is dead. All the children undergoing outpatient treatment during the stay of the researcher in the outpatient service presented a personal functional clinical performance score between 1 and 2 points.

Data collection was performed through the technique of interview using a script with questions for identification of the child and open questions related to the research object, namely: "What does it mean to be sick for you?"; "What do you know about your illness?"; "What changes have taken place in your life after the illness? (family, friends, school)"; "What do you know about your treatment (chemotherapy)?"; "How do you feel when you come to the hospital to make chemotherapy?"; "What do you like to do when you are in the hospital?"; "What do you think about the games at the hospital while you wait to take chemo?"; "Do you think these games help you while you wait to take chemo? In what way?"; "How do you feel when you participate in the games at the hospital while you wait to take chemo?"; and "What is your favorite game? Why?".

The speeches of study participants were recorded and transcribed verbatim. The children participating in this investigation were not identified; they were named as toys/games of their preference, and that were meaningful during their childhood and object of study of this scientific production. The pseudonyms used to name the children were: Race, 10-year-old male child diagnosed with acute lymphoid leu- kemia in June 2014; Painting, 12-year-old female child diagnosed since June of 2013 with acute lymphoid leukemia; Coloring, 6-year-old female child diagnosed 2 years ago with juvenile myelomonocytic leukemia; Ball, 7-year-old female child undergoing treatment for acute lymphoid leukemia since 2013; and Doll, 5-year-old female child diagnosed with acute lymphoid leukemia in December 2013.

A field notebook was used as methodological strategy to record all the observations, experiences and reflections resulting from the encounter with the children during the empirical phase of the study.

This research was grounded on the Humanistic Nursing Theory. This theory emphasizes the existential experience and allows to know the human being in his singularity in a given situation, in order to confirm his existence and to understand his meaning ${ }^{(6)}$.

The study respected the formal requirements contained in national and international standards for research involving human beings. In accordance with the ethical provisions on research involving human beings contemplated in Resolution 466/2012, data collection was only initiated after the approval of the project by the Research Ethics Committee of the Alcides Carneiro University Hospital under a substantiated Opinion, protocol $\mathrm{n}^{\circ}$ 906,886 and CAAE no $36251914,1,0000,5182$. Based on the abovementioned ethical precepts, the proposed work was explained to those interested in participating, making exceptions about the purpose, justification and methodological procedures of the research. The willing nature of the participating was also ensured, by means of the informed consent term in order to obtain the free and adequately informed manifestation of children with cancer. It is worth emphasizing that the cooperation of the children in the present research was ratified by the informed consent term.

\section{Results}

In order to unravel the facets of the relevance of playing to children undergoing chemotherapy tre- 
atment, we initially obtained knowledge about the understanding that the children participating in this research had about their diagnosis and treatment, as well as on the restrictions they experienced, due to their illness and required therapy.

The following reports relate to the understanding of children about the disease that affects them. We have to make radio therapy in the head and have to take chemo, you have to do treatment. Three years, 36 months, as she says, but it's 3 years (Painting). I know I have leukemia, I need a bone marrow transplant, so all my friends are dead because they had to do the transplant, but they did not find, and I have not found it yet, I'm in the queue (Coloring).

As for chemotherapy, the reports emphatically revealed that this was an unpleasant procedure in which a substance was administered to fight the cancer, with the outcome of cure and therefore return to normal activities. To kill the cells that are poisoned. That kills the cells that are with cancer (Race). It kills the bacteria. Chemo is a product that defeats it [the disease] (Ball). I just know the chemo helps me get better. Oh, it does good for health, to improve, but the disease is very bad (Doll). It's bad [responds quickly], chemo. It is that we have to be punched and take it (Coloring).

Stressing the existential experience of having an oncological disease that requires a difficult and painful therapeutic treatment, the testimonies of the children opened space to apprehend the restrictions and deprivations experienced, as a predisposed reality. I do not go to school any more. There are some things that are offensive, there are places where we cannot go, also the school I cannot go. And also there are some friends [pause] that I took, you know, when the person is like so, the person knows who is good or bad, there are some friendships that never mind (Painting). All. The food. That I cannot go to school to study, I cannot play with my friends all the time (Race).

In addition to changes in the child's daily life, including deprivation of school activities, separation from peers, and disruption of friendships and dietary changes, as well as restrictions on performing activities that the children enjoyed such as playing, the process of becoming ill and having to undergo treatment also determined the hospitalization of the children, subjecting them to restrictions and isolation, and exposure to invasive and painful procedures and interventions. It's because the person is hospitalized, then they have to inject, punch the vein, take chemo (Doll). Because you have to come every day to the hospital and also you have to be punched, and stick the little finger at times. When I go to take the chemo, I feel some pain when the needle pierces me, it is an agony (Ball).

Because the procedures cause discomfort and suffering in the outpatient clinic, the children experienced a sense of fear. I may have taken a thousand, a thousand, a thousand, but the person always has that fear at the moment. I take chemo all the time, and I'm always afraid of the needle punch (Painting).

The children's emotional state was compromised during outpatient treatment. They exhibited reactions of aggressiveness and rejection, as well as anger and repression. It was not normal in the past, there were not so many diseases. Everyone now is sick, it's annoying, there are many children also dying. I've met several children who died. The disease kills a lot; it kills a lot of people. Many. This is sad (Race). Trying to explode with rage (Ball).

Some side effects associated with therapy made the situation even more difficult and threatening. In the interviews, the children recalled symptoms often associated with the use of chemotherapeutic drugs permeating their lives and triggering physical and emotional weakness. Nausea [quick response and laughter]. Sometimes it hurts, sometimes it doesn't, I do not know when it will hurt (Race). I used to feel nauseous, but now I do not feel any more, there are people who feel nausea, it depends on the person, I do not feel. But sometimes, when I took it in the vein I used to feel nausea (Painting). I get a stomach ache sometimes (Doll).

In order to alleviate the adverse effects and suffering arising from chemo, playing represented a viable tool to arouse positive feelings such as happiness and satisfaction. It was a distracting resource for children, making time to pass faster and helping to overcome negative feelings and emotions. Nice. We play while we wait to take the chemo, it does not take long (Doll). Cool, cool. Because it distracts me, because time passes faster (Painting). 
Playing of anything makes me forget a lot of things, but I do not even know because I've forgotten [laughs]. Time flies [approves with the head] (Race).

Playing in the outpatient setting means that the children experienced a "better" situation as the games awakened in them a sense of lightness and tranquility. The games gave rise to happiness and fun. Oh, I get better because we have fun and forget everything bad that is happening [balances head positively] (Coloring). Because everyone has fun there and when there is nobody, the little ones make a mess [laughs]. I was sitting still (Race). Happy. My friend is missing the fun [smiles wide] (Painting). I feel very happy at home, here more or less. I like it because it gets really light, calmer. It feels cool, it calms me down (Doll).

Another aspect evidenced in the discourses of the children participating in this study was the ambivalence of sensations related to the chemotherapy. On the one hand, the therapy was considered an unpleasant event and, on the other hand, glimpsed as the possibility of achieving the cure. The day I take chemo and play is good, but when I don't play when I take chemo, this day is bad. But not bad because of the chemo, because the chemo kills the bacteria. It just that it gets boring (Ball). A good day and a boring day; the good day when I take chemo and the boring day when I don't (Coloring). Yeah, taking chemo is bad at the moment. Because before going to chemo I'm good, because when I go to chemo I feel bad (Doll).

Although playing in the ambulatory service is a pleasant experience, two children showed that their greatest desire was to carry out this activity in their homes, a place of protection, shelter and security. I like to play in my house, to play with paint. Here you can only play with these little things (Doll). I like to go home [laughs and looks at mom]. Yeah, I like to play, I like to go home, but I do not like to stay in the hospital (Coloring).

\section{Discussion}

Due to the particularity that distinguishes each individual, the results obtained in this study cannot be extended to all the children affected by cancer undergoing treatment, nor is it possible to generalize the meaning regarding the use of games/toys in waiting rooms of children's clinic.
However, this study draws attention to the existential experience of children in outpatient treatment regarding the importance of playing and contributes to awaken the need to offer them an authentic care based on the valorization of their potentialities, where playing emerges as a feasible tool. This article also allows Nursing professionals to know the importance of playing to children with cancer in chemotherapy treatment and, thus, to ensure its implementation in the outpatient setting.

Based on the reports, we observed that children assimilate and reproduce the technical qualifications of the pathology, medications and procedures, mixing them with their fantasies ${ }^{(7)}$.

It is thus important that the team responsible for providing care for children with cancer in chemotherapy treatment, and especially the Nursing team, establish a transactional relationship capable of awakening an existential consciousness about the lived experience and, thus, reach and recognize its human potential.

The children's perception of chemotherapeutic treatment is motivated by the culture that cancer is an evil that must be overcome. However, it is important to highlight that the treatment of childhood malignant neoplasias begins even before the children adapt to the disease and understand the process they are experiencing. This process is characterized by the fact that it is long and sometimes requires periodic hospitalizations, and exposes the children to painful and aggressive procedures ${ }^{(8)}$.

Before the illness and the need to make chemotherapy, the child's life undergoes several modifications. In addition to preventing schooling and the process of interpersonal interaction, chemotherapy also determines the need for rigorous diet planning during treatment, because children with good nutrition are better able to overcome side effects and successfully cope with administration of higher doses of certain medicinal products ${ }^{(9)}$.

Another aspect that undergoes changes due to the illness and the therapy required by cancer is 
playing activities. Games that require a lot of physical effort should be avoided due to the children's body weakness and the risk of worsening of their clinical condition $^{(10)}$.

In the fight against cancer, the chemotherapeutic intervention interferes significantly in the daily routine of children. The nursing professionals who assist the children must seek strategies to maintain the best quality of life possible during treatment, not concentrating solely on their well-being, but more fully on their existence. They should help them to understand the lived reality and to consider their feelings and behaviors in the light of their experiences ${ }^{(11)}$.

Sometimes the treatment of cancer requires the children's hospitalization, as well as exposure to medical equipment and aggressive treatments, making the process outrageous and painful. It is necessary to establish an inter-subjective and empathic relationship between the nursing and the hospitalized children, mediated by existential meetings aimed at helping them to understand the hospital environment, from the point of view of the experience of the child.

Chemotherapy is connected to several feelings that permeate the daily life of the children under treatment, including fear, sadness, discouragement, hopelessness, grief, distress, anguish, restlessness and impatience. These feelings arise in response to the impact of the diagnosis, the uncertainty about the prognosis and the complexity involved in the chemotherapy treatment ${ }^{(12)}$.

It is worth emphasizing that children may still present aggressive and choleric behaviors as a way of expressing their dissatisfaction with their existential condition determined by the illness and the therapy, because they experience their time wrapped in annoyance, sorrow, solidarity, separation and constant expectation, present in their own real experiences ${ }^{(13)}$.

Local and systemic side effects caused by the medications necessary for the antineoplastic treatment are factors that tend to potentiate the suffering related to chemotherapy. This is because the active principles of chemotherapeutic agents do not specifi- cally act on tumor cells, but they also cause toxicity in healthy tissues, which present rapid cell proliferation $^{(14)}$.

From the valorization of the human potential, it becomes necessary to make available to the children resources that are within their domain to help them deal with their experience. In this perspective are inserted the playful activities in the outpatient environment.

Playing contributes not only to the children's well-being but also acts as a non-pharmacological resource for pain relief. It also contributes to the "better" condition as it allows feelings of pleasure, joy and contentment to maintain the quality of life of children undergoing outpatient chemotherapy.

Playing reduces idleness during the children's stay in the clinic, turning the inactive time into something productive and generator of satisfaction. Moreover, games eliminate negative thoughts related to the suffering that the children face ${ }^{(15)}$.

It should be mentioned that playful activities contribute to the clinical practice and are an important resource to prepare the children for the procedures. They also promote the support and collaboration of the little patients because give them certain control over the reality that they experience, sometimes playing the role of the professionals ${ }^{(16)}$.

Playing favors the creation of an affective bond between the nursing team and the children, mediated by a dialogical presence, allowing the children to expose their feelings and conflicts, from then on, to enable the professionals to understand the effective needs of each one of them so as to offer a care consubstantiated in their singularity and the individuality, through a genuine dialogical relation of calls and effective answers ${ }^{(4)}$.

In spite of outpatient chemotherapy, the reports of the children participating in the study demonstrated a feeling of ambivalence because, at the same time as they correlated with pain and suffering influenced by the procedure itself and by the side effects of the antineoplastic medication, they also hope for healing. 
As far as playing in the chemotherapy outpatient clinic is concerned, the discourses of the children participating in the study also show ambiguity. Although children recognize that the playful activities provide relief, comfort, and intense satisfaction, some reports revealed discontent with the illness and treatment, and that the children would like to be and play at home.

\section{Conclusion}

The investigation shows the ambiguity that permeates the children's imagery regarding chemotherapy. At the same time as this treatment is considered an unpleasant experience, it emerges as necessary for healing. Although games are important in the outpatient chemotherapy service under the children's perception, they prefer to perform them at home, corroborating their dissatisfaction with the situation. Playing represents as a viable tool and give rise to positive feelings such as happiness and satisfaction.

\section{Collaborations}

Morais GSNM contributed with the conception and design, writing of the article, and analysis and interpretation data. França JRS, Duarte MCS, Lopes MMEL and Batista PSS contributed to the relevant critical review of intellectual content. Costa SFG contributed in the relevant critical review of the intellectual content and final approval of the version to be published.

\section{References}

1. Guimarães RCR, Gonçalves RPF, Lima CA, Torres MR, Silva CSO. Nursing actions facing reactions to chemotherapy in oncological patients. Rev Pesqui Cuid Fundam Online. 2015; 7(2):2440-52. doi: http://dx.doi.org/10.9789/2175-5361.2015. v7i2.2440-2552
2. Teixeira HC, Volpini MN. A importância do brincar no contexto da educação infantil: creche e pré-escola. Cad Educ Ens Soc [Internet]. 2014 [citado 2018 jan. 17]; 1(1):76-88. Disponível em: http:// unifafibe.com.br/revistasonline/arquivos/cadernodeeducacao/sumario/31/04042014074001. pdf

3. Silva LF, Cabral IE. Rescuing the pleasure of playing of child with cancer in a hospital setting. Rev Bras Enferm. 2015; 68(3):337-42. doi: http:// dx.doi.org/10.1590/0034-7167.2015680303i

4. Depianti JRB, Silva LF, Carvalho AS, Monteiro ACM. Nursing perceptions of the benefits of ludicity on care practices for children with cancer: a descriptive study. Online Braz J Nurs. 2014; 13(2):158-65. doi: http://dx.doi. org/10.5935/1676-4285.20144314

5. Falqueto J, Farias J. Saturação teórica em pesquisas qualitativas: relato de uma experiência de aplicação em estudo na área de administração. CIAIQ2016 [Internet]. 2016 [citado 2018 jan. 21]; 25:560-9. Disponível em: http://proceedings. ciaiq.org/index.php/ciaiq2016/article/ view/1001/977

6. Paterson JG, Zderad LT. Enfermería humanística. México: Editorial Limusa; 1979.

7. Bossols AMS, Zavaschi ML, Palma RB. A criança frente à doença e à morte: aspectos psiquiátricos. Rev Bras Psicoter [Internet]. 2013 [citado 2018 jan. 17]; 15(1):12-25. Disponível em: http://rbp. celg.org.br/detalhe_artigo.asp?id=108

8. Gomes IP, Lima KA, Rodrigues LV, Lima RAG, Collet N. From diagnosis to survival of pediatric cancer: children's perspective. Texto Contexto Enferm. 2013; 22(3):671-9. doi: http://dx.doi. org/10.1590/S0104-07072013000300013

9. Gomes NS, Maio R. Avaliação subjetiva global produzida pelo próprio paciente e indicadores de risco nutricional no paciente oncológico em quimioterapia. Rev Bras Cancerol [Internet]. 2015 [citado 2018 mar. 25]; 61(3):235-42. Disponível em:http://www.inca.gov.br/rbc/n_61/v03/ pdf/06-artigo-avaliacao-subjetiva-globalproduzida-pelo-proprio-paciente-e-indicadoresde-risco-nutricional-no-paciente-oncologico-emquimioterapia.pdf 
10. Dias JJ, Silva APC, Freire RLS, Andrade ASA. Experience of children with cancer and the importance of recreational activities during hospitalization. Rev Min Enferm. 2013; 17(3):60819. doi: http://www.dx.doi.org/10.5935/14152762.20130045

11. Silva LF, Cabral IE. Rescuing the pleasure of playing of child with cancer in a hospital setting. Rev Bras Enferm. 2015; 68(3):391-7. doi: http:// dx.doi.org/10.1590/0034-7167.2015680303i

12. Almico T, Faro A. Coping of caregivers of children with cancer in chemoterapy process. Psicol Saúde Doenç. 2014; 15(3):723-37. doi: http://dx.doi. org/10.15309/14psd150313

13. Hostert PCCP, Motta AB, Enumo SRF. Coping da hospitalização em crianças com câncer: a importância da classe hospitalar. Estud Psicol. 2015; 32(4):627-39. doi: http://dx.doi. org/10.1590/0103-166X2015000400006
14. Schein CF. Efeitos colaterais da quimioterapia em pacientes oncológicos hospitalizados. Disc Sci [Internet]. 2006 [citado 2018 mar. 25]; 7(1):1017. Disponível em: https://periodicos.unifra.br/ index.php/disciplinarumS/article/view/907

15. Silva DF, Brandão EC. As práticas lúdicas no cotidiano da enfermagem pediátrica. Rev Enferm FACIPLAC [Internet]. 2017 [citado 2018 jan. 17]; 2(2):1-12. Disponível em: http://revista.faciplac. edu.br/index.php/REFACI/article/view/266

16. Ferrari R, Alencar GB, Viana DV. Análise das produções literárias sobre o uso do brinquedo terapêutico nos procedimentos clínicos infantis. Rev Eletr Gestão Saúde. 2012; 3(2):381-94. doi: http://dx.doi.org/10.18673/gs.v3i2.24281 